\title{
Flow behavior of cocoa pulp powder containing maltodextrin
}

\section{Comportamento do escoamento do pó da polpa de cacau contendo maltodextrina}

\author{
Luciana Carneiro Ribeiro ${ }^{1}$, José Maria Correia da Costa ${ }^{1}$, \\ Marcos Rodrigues Amorim Afonso ${ }^{1 *}$ (i) \\ ${ }^{1}$ Universidade Federal do Ceará (UFC), Departamento de Engenharia de Alimentos, Fortaleza/CE - Brasil \\ *Corresponding Author: Marcos Rodrigues Amorim Afonso, Universidade Federal do Ceará (UFC), Departamento \\ de Engenharia de Alimentos, Av. Mister Hull, 2977, Bloco 858, Campus do Pici, CEP: 60356-001, Fortaleza/CE - \\ Brasil, e-mail:m.r.a.afonso@gmail.com
}

Cite as: Ribeiro, L. C., Costa, J. M. C., \& Afonso, M. R. A. (2020). Flow behavior of cocoa pulp powder containing maltodextrin. Brazilian Journal of Food Technology, 23, e2020034. https://doi.org/10.1590/1981-6723.03420

\begin{abstract}
This study aimed to evaluate the influence of maltodextrin addition on the flow properties of cocoa pulp powder obtained by spray and freeze drying. Cocoa pulp samples received $15 \%$ and $30 \%\left(\mathrm{~m} \mathrm{~m}^{-1}\right)$ maltodextrin DE20. Two drying methods were used, spray and freeze drying. Powder morphology was evaluated through scanning electron microscopy (SEM). Wall friction angle, bulk density and tapped density were determined. Carr index (Cl), Hausner ratio (HR) and flow index (FI) were used to evaluate powder flow. The particles powders obtained by spray drying showed rounded shapes, whereas the freeze dried powder showed irregular shapes. Increased maltodextrin concentration in the samples altered the powder particle size by spray drying and powder particle surface by freeze drying. The powder by spray drying of the sample with $30 \%$ of maltodextrin showed smallest wall friction angles, 13.4 to 14.9 . The powder by freeze drying of the samples with $15 \%$ and $30 \%$ of maltodextrin showed wall friction angles between 14.0 and 20.6. Regarding flow, the powders by spray drying containing $30 \%$ of maltodextrin showed the best $\mathrm{Cl}, \mathrm{HR}$ and $\mathrm{Fl}, 24.88,1.33$ and 4.88, respectively, being considered an acceptable flow. According to $\mathrm{Cl}, \mathrm{HR}$ and $\mathrm{FI}$ values, samples with $15 \%$ of maltodextrin produced powder classified as difficult flow in both methods applied. The higher maltodextrin concentration in cocoa pulp, the lower agglomeration in the powder by spray drying and the smoother particles surfaces in the powder by freeze drying. The addition of maltodextrin to the samples, for both drying methods, improve the powder flow and decrease the powder cohesion.
\end{abstract}

Keywords: Drying; Powder fruit; Microscopy; Adjuvant; Carr index; Hausner ratio.

\section{Resumo}

O objetivo deste estudo foi avaliar a influência da adição de maltodextrina nas propriedades de escoamento do pó de polpa de cacau obtido em secagem por aspersão e liofilização. Amostras da polpa de cacau foram adicionadas com 15\% e 30\% ( $\left.\mathrm{m} \mathrm{m}^{-1}\right)$ de maltodextrina DE20. Foram utilizados dois métodos de secagem: por aspersão e liofilização. A morfologia do pó foi avaliada por microscopia eletrônica de varredura (MEV). Foram determinados o ângulo de atrito com a parede, a densidade aparente e a de compactação. O índice de $\mathrm{Carr}(\mathrm{Cl})$, a razão de Hausner (HR) e o índice de fluxo (FI) foram determinados e utilizados para avaliar a fluidez dos pós. As partículas do pó 
obtido por aspersão apresentaram formato arredondado, enquanto as do liofilizado apresentaram formas irregulares. O aumento da concentração de maltodextrina nas amostras alterou o tamanho das partículas do pó obtido por spray dryer e a superfície das partículas daquele obtido por liofilização. O pó obtido por spray dryer, a partir da amostra com 30\% de maltodextrina, apresentou os menores ângulos de atrito com a parede, entre 13,4 e 14,9. Os pós obtidos por liofilização das amostras com 15\% e 30\% de maltodextrina apresentaram ângulos de friç̧ão entre 14,0 e 20,6. Em relação à fluidez, os pós obtidos por spray dryer contendo $30 \%$ de maltodextrina apresentaram os melhores $\mathrm{Cl}$, $\mathrm{HR}$ e Fl, com valores de 24,88, 1,33 e 4,88, respectivamente, classificando-os como de aceitável escoamento. De acordo com os valores de $\mathrm{Cl}, \mathrm{HR}$ e $\mathrm{Fl}$, amostras contendo $15 \%$ de maltodextrina produziram pós classificados como de difícil escoamento em ambas as secagens utilizadas. Quanto maior a concentração de maltodextrina na polpa de cacau, menor a aglomeração nos pós obtidos por spray dryer e mais lisas as superfícies das partículas do pó obtido por liofilização. A adição de maltodextrina nas amostras, em ambos os métodos de secagem, melhora a fluidez e diminui a coesão dos pós.

Palavras-chave: Secagem; Frutas em pó; Microscopia; Adjuvante; Índice de Carr; Relação de Hausner.

\section{Introduction}

Cocoa (Theobroma cacao L.) is a fruit originally from America. Although the seed is the mainly used part of the fruit, the cocoa pulp is nutritionally rich, and has polyphenolic antioxidants, which has led to growing interest for its use (Efraim et al., 2011). Food powders obtained from fruit juices and pulps are characterized by high sugar content and can be used as ingredients or raw material (flour, semolina, dyes, flavorings, etc.), but also in the form of products (Ferrari et al., 2012). The sugars present in the powders are responsible for strong interactions with the water molecules, changing some characteristics of the product and leading to reduced shelf life. Therefore, drying aids, such as carbohydrates and gums, are essential to assist in the drying, improving hygroscopicity, flow, solubility while maintaining important compounds for longer periods of time (Krumreich et al., 2016). Maltodextrin is the carrier agent commonly used in drying due to its high solubility, low hygroscopicity and low cost. In addition, it has well-defined physical properties that facilitates its use as an additive in the industry (Mosquera et al., 2010).

The study on powder flow behavior is essential for the development of processing technologies in industries of produces, powder foods, and pharmaceutics. Determining this behavior is important to provide adequate knowledge for industrial operations such as flow in hoppers and silos, aeration, fluidization, pneumatic transport, mixing, grinding, compaction, dosage, transportation, packaging and storage (Lopes Neto et al., 2009).

Food powders are generally cohesive in nature, and their compressibility is highly correlated with the powder material properties (Aziz et al., 2018). Properties such as internal friction angle, flow function, cohesion, unconfined yield strength, angle of repose, Hausner ratio (HR), and bulk density have been used as qualitative descriptions of food powder flowability (Szulc \& Lenart, 2010). Therefore, this study aimed to evaluate the influence of maltodextrin addition on the flow properties of cocoa pulp powder obtained by spray and freeze drying.

\section{Material and methods}

\subsection{Sample preparation}

The frozen cocoa pulp (moisture of 89.33\%) was obtained from a local market (Fortaleza, CE, Brazil). To reduce its viscosity, the pulps were diluted in water in the mass proportion of 1 part of water for every 2.3 parts of pulp. Then, samples with maltodextrin DE20 concentrations of $15 \%$ and $30 \%\left(\mathrm{~m} \mathrm{~m}^{-1}\right)$ were prepared through dilution in Turratec TE 102 homogenizer, under 14,000 rpm rotation for $160 \mathrm{~s}$. 


\subsection{Sample drying}

After sample preparation, the cocoa pulp powders were obtained through spray and freeze drying. Spray drying was conducted using an MSD 1.0 spray dryer from LabMaq do Brasil, with spray nozzle of $1.2 \mathrm{~mm}$ in diameter. The spray dryer was adjusted under the following operating conditions: flow rates of $3.5 \mathrm{~m}^{3} / \mathrm{min}$ for heated air, $5 \times 10^{-4} \mathrm{~m}^{3} / \mathrm{h}$ for samples, $0.003 \mathrm{~m}^{3} / \mathrm{min}$ for pressurized air, and drying air temperature at $178^{\circ} \mathrm{C}$. In freeze drying, the samples were frozen up to $-38^{\circ} \mathrm{C}$ in ultra-freezer, model CL90 - 40V from the company Terroni. After that, they were dehydrated for $24 \mathrm{~h}$ in an LS3000 freeze dryer from Terroni Equipamentos Científicos Ltda, reaching final pressures between 20 and $26.7 \mathrm{~Pa}$ and temperature of $25^{\circ} \mathrm{C}$. After each dehydration, the samples passed through $500 \mu \mathrm{m}$ ( $35 \mathrm{mesh}$ ) sieve for particle size homogenization.

\subsection{Powder morphology}

The powders morphologies were evaluated under a scanning electron microscope Zeiss, Quanta FEG450FSQC model, from FEI Thermo Scientific. The images were captured and scanned, operating at $10 \mathrm{kV}$, with magnification of 2000x.

\subsection{Flow evaluation}

The samples' powder flow was evaluated using the Powder Flow Tester (PFT) device from Brookfield Engineering Laboratories. For each sample, we obtained the wall friction angle, bulk density, and tapped density. The samples, in duplicates, with $20 \mathrm{~g}$ pulp powders containing $15 \%$ and $30 \%$ of maltodextrin DE20 were placed on circular stainless-steel trays and transferred to the device, which applied varied stresses on the surface of the powders through a circular stainless-steel disc to measure the parameters. In addition, we determined relationships between unconfined yield strengths and major consolidation stresses applied to the samples were determined. From the densities, the Carr index (Equation 1) and Hausner ratio (Equation 2), and the powders were classified with respect to their flowability, for the ranges presented in Table 1, according to Aziz et al. (2018).

$$
\begin{aligned}
& \mathrm{CI}=\frac{\alpha_{\mathrm{T}}-\alpha_{\mathrm{B}}}{\alpha_{\mathrm{T}}} \times 100 \\
& \mathrm{HR}=\frac{\alpha_{\mathrm{T}}}{\alpha_{\mathrm{B}}}
\end{aligned}
$$

where: $\mathrm{CI}$ is Carr index (\%); HR is Hausner ratio; $\alpha_{\mathrm{T}}$ is tapped density $\left(\mathrm{kg} / \mathrm{m}^{3}\right)$ and $\alpha_{\mathrm{B}}$ is bulk density $\left(\mathrm{kg} / \mathrm{m}^{3}\right)$

Table 1 shows the values of the Carr index and Hausner ratio in terms of the flow property that indicates the quality of the powder. Based on the quality of powder, the range from excellent to passable is acceptable, and others refer to lower quality of the powder (Shishir et al., 2014).

Table 1. Powder flowability classification (Aziz et al., 2018).

\begin{tabular}{ccc}
\hline Flowability & Carr Index, CI(\%) & Hausner Ratio, HR \\
\hline Excellent & $0-10$ & $1.00-1.11$ \\
\hline Good & $11-15$ & $1.12-1.18$ \\
\hline Adequate & $16-20$ & $1.19-1.25$ \\
\hline Acceptable & $21-25$ & $1.26-1.34$ \\
\hline Difficult & $26-31$ & $1.35-1.45$ \\
\hline Very difficult & $32-37$ & $1.46-1.59$ \\
\hline Excessively difficult & $>38$ & $>1.60$ \\
\hline
\end{tabular}


The powder's flow index (FI) was determined according to Teunou et al. (1999), as the inverse of the inclination of the line fitted to the data of the unconfined yield strengths and major consolidation stresses. Powder flow behavior was evaluated according to Lopes Neto et al. (2009).

\section{Results and discussion}

The powders' microstructures obtained by spray and freeze drying can be observed in Figure 1. The particles of the samples obtained by spray drying (Figure 1A and B) exhibit, in general, rounded shapes with heterogeneous particle size. The spherical or oval shapes exhibited by the particles obtained by spray drying occur because of the drying conditions, being desirable due to the higher retention of aromas, higher bulk density and better flow (Santana et al., 2014). Smooth and spherical particles are desirable because of good aroma retention, due to lowest surface to volume ratio, and higher bulk density that reduces packing costs (Santana et al., 2016). In the micrographs of the freeze dried powders (Figure 1C and D), we observed irregular shapes and sizes, with the presence of pores, especially in the powder containing $15 \%$ maltodextrin, highlighted by arrows in Figure 1C. Conceição et al. (2016), analyzed the particles of freeze dried guava pulp powders and stated that the presence of pores is explained by the sublimation of ice present in the samples during freeze drying.

A

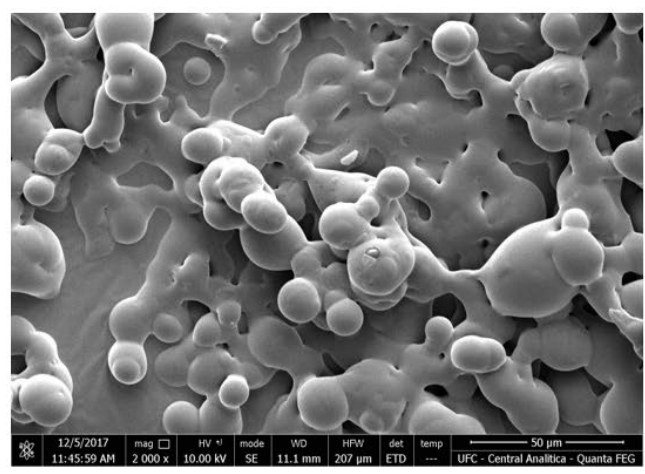

C

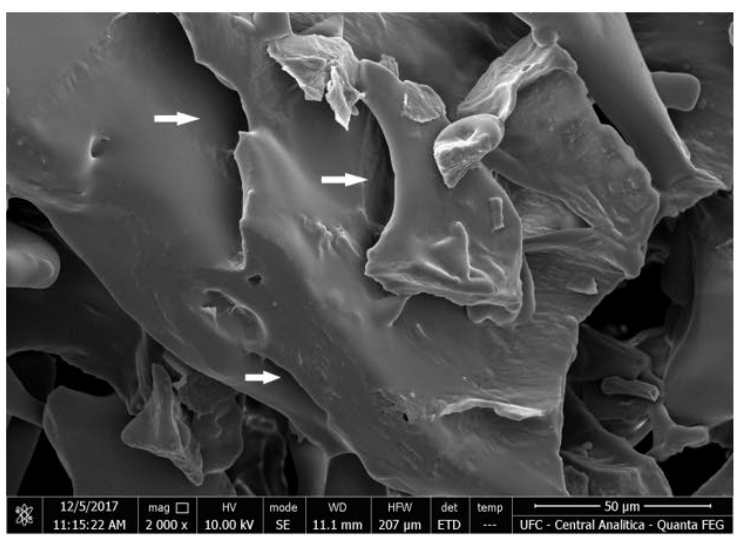

B

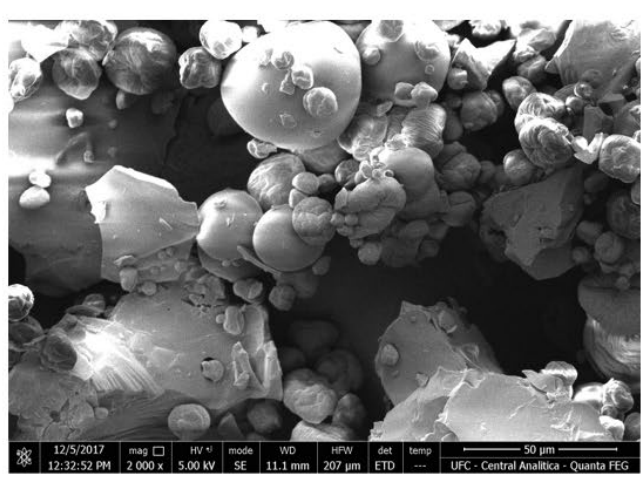

D

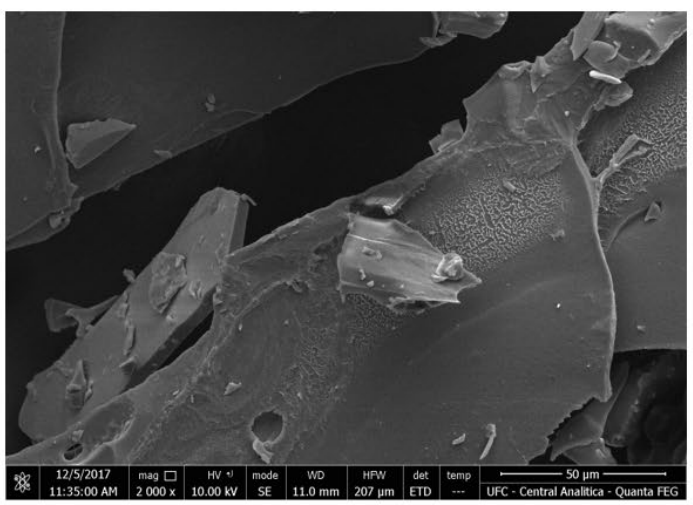

Figure 1. Micrographs of cocoa pulp powder obtained by spray drying with $15 \%$ (A) and $30 \%$ (B) of maltodextrin and freeze drying with $15 \%$ (C) and $30 \%$ (D) of maltodextrin.

By evaluating the effect of adding drying adjuvant to the microstructure of the powders obtained by spray drying (Figure 1A and B), we observed an increase in particle diameter as the maltodextrin concentration increased. Tonon et al. (2009) found similar results and related this effect to the increase in the viscosity of 
the mixture, so that the higher the viscosity of the liquid, the larger the drops formed during the spraying and, therefore, the larger the powder particles obtained.

In freeze dried particles (Figure 1C and D) showed no effect of increased size as a function of maltodextrin concentration. On the other hand, the addition of maltodextrin to cocoa pulp produced powders with smoother surfaces. This behavior was verified by Afonso et al. (2019) in freeze dried mango pulp powder. According to Tonon et al. (2009), smoother surfaces can improve the flow characteristics of the material.

We also observed that samples obtained by spray drying with the lowest concentration of maltodextrin (15\%) resulted in powders with formation of bridges between particles, so that they did not separate (Figure 1A). Mishra et al. (2014) observed the same formations of bridges between particles in amla juice powder with maltodextrin (9\%). These bridges may be a result of the hygroscopicity of the fruit powders, leading to the formation of agglomerates. Samples with higher concentration of maltodextrin (Figure 1B) did not show bridges between particles.

The results of density of cocoa pulp powders obtained by spray and freeze drying (Table 2) are presented as bulk density and tapped density. According to Campos \& Ferreira (2013), the increase in the density of a powder as a function of the applied stresses is the result of its compaction.

Table 2. Density, friction angle, Carr index, Hausner ratio and flow index of cocoa pulp powders obtained by spray and freeze drying, added with different maltodextrin concentrations.

\begin{tabular}{|c|c|c|c|c|c|c|c|c|}
\hline \multirow{2}{*}{ Drying } & \multirow{2}{*}{$\begin{array}{c}\text { Samples }^{\mathrm{a}} \\
(\%)\end{array}$} & \multicolumn{2}{|c|}{ Density $\left(\mathbf{k g} / \mathbf{m}^{3}\right)$} & \multicolumn{2}{|c|}{ Friction angle ${ }^{\mathrm{b}}\left(^{\circ}\right)$} & \multirow{2}{*}{$\mathbf{C I}^{\mathbf{c}}$} & \multirow{2}{*}{$\mathbf{H R}^{\mathrm{d}}$} & \multirow{2}{*}{$\mathbf{F} \mathbf{I}^{\mathrm{e}}$} \\
\hline & & Bulk & Tapped & Lower & Upper & & & \\
\hline \multirow{2}{*}{$\begin{array}{l}\text { Spray } \\
\text { drying }\end{array}$} & 15 & 549.0 & 764.3 & 17.0 & 26.2 & 28.17 & 1.39 & 3.75 \\
\hline & 30 & 551.6 & 734.3 & 13.4 & 14.9 & 24.88 & 1.33 & 4.88 \\
\hline \multirow{2}{*}{$\begin{array}{l}\text { Freeze } \\
\text { drying }\end{array}$} & 15 & 304.4 & 418.2 & 16.1 & 20.6 & 27.21 & 1.37 & 3.82 \\
\hline & 30 & 366.9 & 493.4 & 14.0 & 16.0 & 25.64 & 1.34 & 4.62 \\
\hline
\end{tabular}

${ }^{\mathrm{a}}$ Concentration of maltodextrin DE20, $\left(\mathrm{m} \mathrm{m}^{-1}\right)$. ${ }^{\mathrm{b}}$ Friction angle with the smooth steel wall. ${ }^{\mathrm{c}}$ Carr index. ${ }^{\mathrm{d}}$ Hausner ratio. ${ }^{\mathrm{e}} \mathrm{Flow}$ index.

We observed that the increase in added maltodextrin concentration increased the density of the freeze dried powders (Table 2). The addition of maltodextrin increases the molecular weight of particles, and the heavier the material, the more easily it settles in the spaces between particles, occupying lower volume and resulting in higher density (Tonon et al., 2009). According to Mohammed et al. (2011), particle shape, roughness, cohesion, and agglomeration also influence the bulk density of the powders. In the powders obtained by spray drying, the opposite effect was observed on tapped density; the powder containing $30 \%$ maltodextrin showed lower density in comparison to the powder with $15 \%$. This was probably due to the large number of bridges between particles (Figure 1A), resulting in a more agglomerated powder and, therefore, with higher tapped density.

The addition of maltodextrin to the pulp directly interfered with the wall friction angle, and it decreased with the increase in the concentration of this adjuvant for both drying processes (Table 2). Afonso et al. (2019) observed the same behavior in mango pulp powders containing maltodextrin. The friction between the powder and a wall is related to the resistance to flow existing between the powder particles and the wall material. Higher values of wall friction result in higher loads transferred to the silo wall surfaces, necessary to ensure a mass flow in the funnel (Iqbal \& Fitzpatrick, 2006). Therefore, the lower the value of this angle, the lower the slope needed by a wall to ensure the powders' flow (Afonso et al., 2019).

Regarding the drying processes adopted for the samples containing $30 \%$ maltodextrin, it was found that lower friction angles were obtained in the spray drying compared to those obtained in the freeze drying. This result is due to the amorphous powder form (Figure 1D) because of the freeze drying process. Fast freezing 
prior to freeze drying avoids solutes crystallization which converted into amorphous solids at the end of the process (Einfal et al., 2013). Amorphous solids promoting larger points of contact between particles and walls, consequently compromising the powders' flow. According to Lopes Neto et al. (2014), the greater the roughness of the surface of the particle and/or the wall, the larger the frictional force absorbed by it. For spray drying samples with $15 \%$ maltodextrin, the opposite effect was observed. The powder samples had slightly higher values (Table 2), despite the smooth particle surface. This behavior is explained by the agglomeration present between the particles of this sample, as observed in Figure 1A. Crowley et al. (2014) reported in their study with concentrated protein powders that the increase in wall friction angle is probably due to the increase in the surface area of contact between particle and wall.

Flow and cohesion are important properties of dry particles and can be evaluated using the Carr index (CI) and Hausner ratio (HR), respectively. CI is also used to express the compressibility of a powder, where high values mean low flowability and high compressibility. HR is used to evaluate powder cohesion, where low values represent powders with good flowability (Aziz et al., 2018). Based on the results presented, we observed that maltodextrin directly influences flowability and cohesion of the powders. According to the results (Table 2) and classification in Table 1, spray dried cocoa pulp powder containing 30\% maltodextrin is classified as of acceptable flowability and freeze dried with same maltodextrin concentration is classified between as of acceptable and as of difficult. All the samples containing $15 \%$ of the adjuvant are classified as of difficult flowability. Zea et al. (2013), applying drying by freeze drying, found CI of 27.2 and HR of 1.37 for guava pulp powder and CI of 34.9 and HR of 1.53 for pitaya pulp powder. These authors attributed the difference between the values found to the average particle sizes, stating that powders with smaller particles have their flowability compromised. Saifullah et al. (2016) claim that the size and shape of the particles of the powders influence their flowability.

Drying method as well as powder composition, containing drying adjuvants, can influence the flowability of the powders (Aziz et al., 2018). Zea et al. (2013), in the freeze drying of pitaya, classified the powder as of very difficult flowability, and Yusof et al. (2012), using a drying oven, classified it as of good flowability. Aziz et al. (2018) report that the larger size and irregular forms of particles of the powder obtained by oven drying are the main reason for its better flowability in comparison to the powders obtained by spray and freeze drying.

Regarding flow index (FI), according to Bhandari et al. (2013), powder is classified as cohesive when 2.0 $<$ FI $<4.0$ and as easy flow when $4.0<\mathrm{FI}<10.0$. The results of flow indices (FI) (Table 2), we observed that those containing $15 \%$ maltodextrin presented values below 4 , being classified as cohesive. Powders containing $30 \%$ maltodextrin were classified as easy flowing, with a slight difference between the powders obtained by spray and freeze drying. The particles structure (Figure 1A and B) may explain the higher cohesiveness of the powders containing $15 \%$ maltodextrin because they have bridges among themselves in those obtained by spray drying and rougher surfaces in those obtained by freeze drying. Mohammed et al. (2011) state that irregularities on the particles' surfaces cause an interconnection between them, increasing the resistance to flow. Afonso et al. (2019) observed the same behavior in mango pulp powders, in which the highest values of FI (4.29 and 4.52) were found in those with higher concentrations of maltodextrin, 10 and $15 \%$, respectively.

\section{Conclusions}

The powders' microstructures obtained by spray and freeze drying are distinct, rounded, and irregular shapes, respectively. The cocoa pulp powders are influenced by the maltodextrin concentration. Higher maltodextrin concentration led to lower agglomeration in the powder obtained by spray drying, smoother particles surfaces in the powder obtained by freeze drying. 
The addition of maltodextrin to the samples, for both drying methods, improved powder flow and decrease powder cohesion. Cocoa pulp powders containing 30\% of maltodextrin showed better flow properties and were classified as acceptable flowability.

\section{Acknowledgements}

This work was supported by the Coordenação de Aperfeiçoamento de Pessoal de Nivel Superior - Brasil (CAPES).

\section{References}

Afonso, M. R., Rodrigues, B. K., Costa, J., Rybka, A. C. P., \& Wurlitzer, N. J. (2019). Microstructure and flow properties of lyophilized mango pulp with maltodextrin. Revista Brasileira de Engenharia Agrícola e Ambiental, 23(2), 133-137. http://dx.doi.org/10.1590/1807-1929/agriambi.v23n2p133-137

Aziz, M., Yusof, Y. A., Blanchard, C. L., Saifullah, M., Farahnaky, A., \& Scheiling, G. (2018). Material properties and tableting of fruit powders. Food Engineering Reviews, 10(2), 66-80. http://dx.doi.org/10.1007/s12393-018-9175-0

Bhandari, B., Bansal, N., Zhang, M., \& Schuck, P. (Eds.). (2013) Handbook of food powders: Processes and properties (Woodhead Publishing in Food Science, Technology and Nutrition, No. 255, 660 p.). Oxford: Woodhead Publishing.

Campos, M. M., \& Ferreira, M. C. (2013). A comparative analysis of the flow properties between two alumina-based dry powders. Advances in Materials Science and Engineering, 2013, 1-8. http://dx.doi.org/10.1155/2013/519846

Conceição, M. C., Fernandes, T., \& Resende, J. V. (2016). Stability and microstructure of freeze dried guava pulp (Psidium guajava L.) with added sucrose and pectin. Journal of Food Science and Technology, 53(6), 2654-2663. PMid:27478221. http://dx.doi.org/10.1007/s13197-016-2237-5

Crowley, S. V., Gazi, I., Kelly, A. L., Huppertz, T., \& O'Mahony, J. A. (2014). Influence of protein concentration on the physical characteristics and flow properties of milk protein concentrate powders. Journal of Food Engineering, 135, 31-38. http://dx.doi.org/10.1016/j.jfoodeng.2014.03.005

Efraim, P., Alves, A. B., \& Jardim, D. C. P. (2011). Polifenóis em cacau e derivados: Teores, fatores de variação e efeitos na saúde. Brazilian Journal of Food Technology, 14(3), 181-201. http://dx.doi.org/10.4260/BJFT2011140300023

Einfal, T., Planinšek, O., \& Hrovat, K. (2013). Methods of amorphization and investigation of the amorphous state. Acta Pharmaceutica, 63(3), 305-334. PMid:24152894. http://dx.doi.org/10.2478/acph-2013-0026

Ferrari, C. C., Ribeiro, C. P., \& Aguirre, J. M. (2012). Secagem por atomização de polpa de amora-preta usando maltodextrina como agente carreador. Brazilian Journal of Food Technology, 15(2), 157-165. http://dx.doi.org/10.1590/S198167232012005000009

Iqbal, T., \& Fitzpatrick, J. J. (2006). Effect of storage conditions on the wall friction characteristics of three food powders. Journal of Food Engineering, 72(3), 273-280. http://dx.doi.org/10.1016/j.jfoodeng.2004.12.007

Krumreich, F., D'Avila, R., Freda, S., Chim, J., \& Chaves, F. (2016). Análises físico-químicas e estabilidade de compostos bioativos presentes em polpa de uvaia em pó obtidos por métodos de secagem e adição de maltodextrina e goma arábica. Revista Thema, 13(2), 4-17. http://dx.doi.org/10.15536/thema.13.2016.4-17.351

Lopes Neto, J. P., Nascimento, J. W. B., \& Fank, M. Z. (2014). Forças verticais e de atrito em silos cilíndricos com fundo plano. Revista Brasileira de Engenharia Agrícola e Ambiental, 18(6), 652-657. http://dx.doi.org/10.1590/S1415-43662014000600013

Lopes Neto, J. P., Nascimento, J. W. B., \& Silva, V. R. (2009). Efeito do tempo de armazenagem de rações avícolas no dimensionamento de silos. Engenharia Agrícola, 39(4), 518-527. http://dx.doi.org/10.1590/S0100-69162009000400002

Mishra, P., Mishra, S., \& Mahanta, C. L. (2014). Effect of maltodextrin concentration and inlet temperature during spray drying on physicochemical and antioxidant properties of amla (Emblica officinalis) juice powder. Food and Bioproducts Processing, 92(3), 252-258. http://dx.doi.org/10.1016/j.fbp.2013.08.003

Mohammed, S. A., Abdullah, E. C., Geldart, D., \& Raman, A. A. A. (2011). Measuring powder flowability with a modified Warren Spring cohesion tester. Particuology, 9(2), 148-154. http://dx.doi.org/10.1016/j.partic.2010.10.004

Mosquera, L. H., Moraga, G., \& Martínez-Navarrete, N. (2010). Effect of maltodextrin on the stability of freeze dried borojó (Borojoa patinoi Cuatrec.) powder. Journal of Food Engineering, 97(1), 72-78. http://dx.doi.org/10.1016/j.jfoodeng.2009.09.017

Saifullah, M., Yusof, Y. A., Chin, N. L., \& Aziz, M. G. (2016). Physicochemical and flow properties of fruit powder and their effect on the dissolution of fast dissolving fruit powder tablets. Powder Technology, 301, 396-404.

http://dx.doi.org/10.1016/j.powtec.2016.06.035

Santana, A. A., Oliveira, R. A., Kurozawa, L. E., \& Park, K. J. (2014). Microencapsulation of pequi pulp by spray drying: Use of modified starches as encapsulating agent. Engenharia Agrícola, 34(5), 980-991. http://dx.doi.org/10.1590/S010069162014000500017

Santana, A., Kurozawa, L., Oliveira, R., \& Park, K. (2016). Spray drying of pequi pulp: Process performance and physicochemical and nutritional properties of the powdered pulp. Brazilian Archives of Biology and Technology, 59(0), e16150362. http://dx.doi.org/10.1590/1678-4324-2016150362 
Shishir, M. R. I., Taip, F. S., Aziz, N. A., \& Talib, R. A. (2014). Physical properties of spray-dried pink gava (Psidium guajava) powder. Agriculture and Agricultural Science Procedia, 2, 74-81. http://dx.doi.org/10.1016/j.aaspro.2014.11.011

Szulc, K., \& Lenart, A. (2010). Effect of aglomeration on flowability of baby food powders. Journal of Food Science, 75(5), e276e284. PMid:20629874. http://dx.doi.org/10.1111/j.1750-3841.2010.01634.x

Teunou, E., Fitzpatrick, J. J., \& Synnott, E. C. (1999). Characterisation of food powder flowability. Journal of Food Engineering, 19(1), 31-37. http://dx.doi.org/10.1016/S0260-8774(98)00140-X

Tonon, R. V., Brabet, C., \& Hubinger, M. D. (2009). Influência da temperatura do ar de secagem e da concentração de agente carreador sobre as propriedades físico-químicas do suco de açaí em pó. Food Science and Technology), 29(2), 444-450. http://dx.doi.org/10.1590/S0101-20612009000200034

Yusof, Y. A., Mohd Salleh, F. S., Chin, N. L., \& Talib, R. A. (2012). The drying and tabletting of pitaya powder. Journal of Food Process Engineering, 35(5), 763-771. http://dx.doi.org/10.1111/j.1745-4530.2010.00625.x

Zea, L. P., Yusof, Y. A., Aziz, M. G., Ling, C. N., \& Amin, N. A. M. (2013). Compressibility and dissolution characteristics of mixed fruit tablets made from guava and pitaya fruit powders. Powder Technology, 247, 112-119.

http://dx.doi.org/10.1016/j.powtec.2013.06.032

Funding: None. 